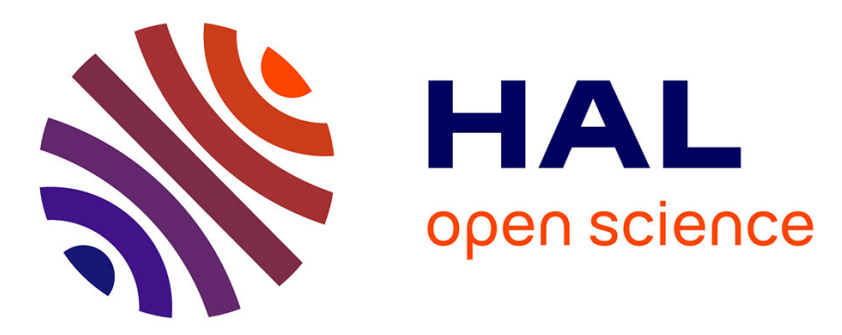

\title{
Adiponectin and leptin serum concentrations in patients with rheumatoid arthritis
}

Bożena Targońska-Stępniak, Magdalena Dryglewska, Maria Majdan

\section{To cite this version:}

Bożena Targońska-Stępniak, Magdalena Dryglewska, Maria Majdan. Adiponectin and leptin serum concentrations in patients with rheumatoid arthritis. Rheumatology International, 2009, 30 (6), pp.731-737. 10.1007/s00296-009-1053-x . hal-00568303

\section{HAL Id: hal-00568303 https://hal.science/hal-00568303}

Submitted on 23 Feb 2011

HAL is a multi-disciplinary open access archive for the deposit and dissemination of scientific research documents, whether they are published or not. The documents may come from teaching and research institutions in France or abroad, or from public or private research centers.
L'archive ouverte pluridisciplinaire HAL, est destinée au dépôt et à la diffusion de documents scientifiques de niveau recherche, publiés ou non, émanant des établissements d'enseignement et de recherche français ou étrangers, des laboratoires publics ou privés. 


\section{„Adiponectin and leptin serum concentrations in patients with rheumatoid arthritis”.}

Bożena Targońska-Stępniak ( $\bowtie)$, Magdalena Dryglewska, Maria Majdan

Department of Rheumatology and Connective Tissue Diseases, Medical University of Lublin, ul. Jaczewskiego 8, 20-950 Lublin, Poland

Tel: +48817244790; Fax: +48817244515

E-mail addresses: bozena.stepniak@am.lublin.pl, magda.dryglewska@am.lublin.pl, maria.majdan@am.lublin.pl,

\section{Introduction}

Rheumatoid arthritis (RA) is a chronic, systemic, inflammatory disease, which affects predominantly synovial joints, causing irreversible joint destruction. Although RA is considered to be a non-fatal disease, higher overall mortality is associated with the disease. Life expectancy in RA patients (pts) is reduced by an average of 3 to 18 years in comparison with non RA population $[1,2]$. One of the most frequent causes of death is cardiovascular disease (CVD), due to the development of premature, accelerated atherosclerosis $[1,2,3]$. Obesity is an established risk factor for coronary artery disease (CAD) and increased mortality in the general population. However, chronic RA inflammation is accompanied by loss of body cell mass (BCM), defined as rheumatoid cachexia [1]. White adipose tissue (WAT) is the main energy store of the body, involved in regulation of energy homeostasis and metabolism. WAT is also currently considered a highly active endocrine organ, that produces a number of biologically active molecules, called adipokines $[4,5,6]$. More than 50 adipokines have been identified up till now: chemokines, cytokines [tumor necrosis factor- $\alpha$ (TNF- $\alpha$ ), interleukin-1 $\beta$ (IL-1 $\beta$ ), IL-6, IL-8, IL-10], complement system proteins, proteins involved in hemostasis, glucose homeostasis (adiponectin, resistin), lipid metabolism, angiogenesis and appetite regulation (leptin) [4, 7].

Adiponectin is a protein, mainly produced by adipocytes and abundantly present in the circulation, accounting for $0,01 \%$ of total plasma protein. It is associated with glucose and 
lipid metabolism. Adiponectin exerts anti-inflammatory action, which results from the reduction of secrection and activity of TNF- $\alpha$ and IL-6, as well as induction of Il-10 and IL-1 receptor antagonist (IL-1Ra) [4]. Decreased adiponectin levels in hypertensive pts are correlated with endothelial dysfunction, which represents the earliest stage of atherosclerosis. Higher adiponectin levels are linked with a lower risk of myocardial infarction [8].

Leptin is a peptide, produced mainly by WAT cells and its circulating levels are directly correlated with WAT mass. The main role of leptin is the regulation of body weight by inhibiting food intake and stimulation of energy expenditure at the hypothalamic level [9]. Leptin levels increase during infection and inflammation, as a result of enhanced production, mediated by pro-inflammatory cytokines (TNF- $\alpha$, IL-1 $\beta$, IL-6). Leptin induces neutrophil chemotaxis, activates monocytes and macrophages, enhancing their phagocytic activity. It also regulates $\mathrm{T}$-cell proliferation and acivity, driving $\mathrm{T}$-cell differentiation toward $\mathrm{Th}_{1}$ response, accounting for pro-inflammatory activity $[9,10]$. On the other hand, it has been reported, that leptin may also stimulate production of anti-inflammatory cytokines by monocytes and macrophages [11].

Conflicting data on adipokines' role in RA have been reported. Leptin concentrations were found to be similar $[12,13,14,15,16]$, lower [17], or higher [18, 19] in comparison with healthy controls or with pts with osteoarthritis (OA) [20]. Plasma levels of adiponectin, leptin and visfatin were found to be increased in RA pts [21] or did not differ significantly in RA pts and in healthy controls [22].

The aim of the study was to investigate adiponectin and leptin concentrations in a group of RA pts in relation with different disease duration and activity.

\section{Materials and methods}

The study group consisted of 80 consecutive RA pts treated in the Department of Rheumatology and Connective Tissue Diseases, Medical University of Lublin. All patients 
fulfilled the American College of Rheumatology criteria for RA diagnosis [23]. Informed consent was obtained from the patients according to the Declaration of Helsinki. The Ethical Committee of the Medical University of Lublin approved the design of the study.

Patients' charts were reviewed for demographic information, clinical diagnosis, radiographic information. Erosive form of RA was diagnosed in those pts who presented erosions on joint surfaces of bones in radiograms of hands and/or feet, according to Steinbrocker et al.'s criteria [24]. Extraarticular symptoms observed in the pts included: rheumatoid nodules, amyloidosis, sicca syndrome, interstitial lung disease. Disease activity was determined using the 28 joints Disease Activity Score (DAS28), calculated with the number of swollen and tender joints, patient's global assessment of disease activity and erythrocyte sedimentation rate (ESR).

Routine laboratory data were determined in all patients: C-reactive protein (CRP), ESR, creatinine, hemoglobin (Hb), erythrocyte (ERY) and platelet (PLT) count. Modification of diet in renal diseases (MDRD) was calculated for every patient to estimate the glomerular filtration rate (GFR) using serum creatinine concentration and demographic factors [25]. Serum level of CRP was measured by immunoturbidimetric assay, with the upper limit of the normal range at $5 \mathrm{mg} / \mathrm{l}$. Total cholesterol (TC), high-density lipoproteins (HDL) cholesterol, triglycerides (TG) were also measured using the standard enzymatic technique (BIOMAXIMA). Low density lipoproteins (LDL) cholesterol was calculated according to the Friedewald formula. Assessment of nutritional status markers [serum albumin, body mass index (BMI), tricipital skin fold (TSF)] was performed. Serum albumin was measured by photometric test with bromocresol green (normal range 3,8- 5,1 g/dl). TSF was measured in both upper limbs, in the mid-point between acromion and olecranon with a Harpenden calliper. The mean of these two measures was calculated for every patient. Although a long disease duration was noticed in half of our pts, the signs of malnutrition syndrome $(\mathrm{BMI}<20$ $\mathrm{kg} / \mathrm{m}^{2}$ and albumin level $<3 \mathrm{~g} / \mathrm{dl}$ ) were observed only in one female patient. 
Serum samples were obtained and stored at $-80^{\circ} \mathrm{C}$. Adiponectin was determined by a commercial enzyme-linked immunosorbent assay (ELISA) (Human Adiponectin Quantikine, R\&D, Germany). The normal range of serum adiponectin according to manufacturer's data was between 0,87 and $21,4 \mathrm{ug} / \mathrm{ml}$ (mean 6,64); the mean detection limit was $0,246 \mathrm{ng} / \mathrm{ml}$. Leptin was determined by a commercial enzyme-linked immunosorbent assay (ELISA) (Human Leptin Quantikine, R\&D, Germany). The normal range of serum leptin according to manufacturer's data was in women between 3,88 and $77,27 \mathrm{ng} / \mathrm{ml}$ (mean 20,68); in men between 2,21 and 11,15 ng/ml (mean 4,76); detection limit 7,8 pg/ml.

Statistics. Correlation between quantitative variables was assessed by Spearman's correlation coefficients. In order to compare subgroups of patients, Student's test or non-parametric Mann-Whitney $U$ test, respectively, were used. For all tests, $P$ values less or equal to 0,05 were considered significant.

\section{Results.}

\section{Demographic and disease-related variables}

Table I presents the basic characteristics of the study group. The mean number of tender joints was 9,61 (7,2) (range 0-28), the mean number of swollen joints was 7,1 (5,1) (range 0- 19). The mean patient's global assessment of disease activity (visual analogue scale 0 - $100 \mathrm{~mm}$ ) was 52,9 (24,1) (range 0-93). High disease activity (DAS28 > 5,1) was noted in 50 pts $(62,5 \%)$ (47 women and 3 men) and moderate or low disease activity (DAS28 $\leq 5,1)$ in 30 pts (37,5\%) (25 women and 5 men). Table II presents differences between pts with long-standing RA (disease duration $>10$ years) and with shorter disease duration ( $\leq 10$ years).

All the patients were treated in the past with at least 1 disease modifying antirheumatic drug (DMARD) which included: methotrexate (MTX), leflunomide (LEF), sulphasalazine (SS), chloroquine (HQ), intramuscular gold salts (GS), cyclosporin A (CYA), cyclophosphamide (CYC). At the time of evaluation 77 pts were treated with DMARDs: MTX (27 pts, 35,1\%), 
LEF (23 pts, 29,9\%), SS (5 pts, 6,5\%), HQ (3 pts, 3,9\%), CYA (2 pts, 2,6\%), CYC (2 pts, 2,6\%), combination of MTX and LEF (7 pts, 9,1\%), MTX and CYA (4 pts, 5,2\%), MTX and Infliximabe (3 pts, 3,9\%), MTX and Etanercept (1 pts, 1,3\%). In 47 pts (58,8\%) low-dose prednisone (5- $10 \mathrm{mg} /$ day) was used in the treatment.

\section{Serum adiponectin concentration}

The mean (SD) adiponectin serum concentration in all the pts was $15,2(9,4) \mathrm{ug} / \mathrm{ml}$ (range 2,95- 58,89) and maintained within the normal range. Adiponectin levels did not differ significantly in women and in men $[15,5(9,6) \mathrm{ug} / \mathrm{ml}$ vs $11,4(7,9) \mathrm{ug} / \mathrm{ml}$. There were no correlations between adiponectin and BMI as well as TSF.

In pts with long-standing RA adiponectin levels were significantly higher than in pts with disease duration $<10$ years $[17,7(11,3) \mathrm{ug} / \mathrm{ml}$ (range 2,95- 58,9) vs $12,7(6,4) \mathrm{ug} / \mathrm{ml}$ (range 4,0- 31,1) (p=0,047) (Fig. 1)]. Serum adiponectin levels correlated positively both with the age of pts $\left(r_{S}=0,32, p=0,003\right)$ and the disease duration $\left(r_{S}=0,38, p=0,0006\right)$ (Tabb. III). There was a significant negative correlation between adiponectin concentration and MDRD GFR $\left(r_{S}=-0,23, p=0,04\right)($ Tab. III).

A negative correlation was found between adiponectin level and the number of swollen joints $\left(r_{S}=-0,26, p=0,02\right)$. There was also a strong positive correlation between serum adiponectin and HDL-cholesterol $\left(\mathrm{r}_{\mathrm{S}}=0,40, \mathrm{p}=0,0003\right)$ (Tab. III).

\section{Serum leptin concentration}

The mean (SD) leptin serum concentration was higher in women 11,13 $(9,8) \mathrm{ng} / \mathrm{ml}$ (range 0,947,6) than in men $3,6(5,6) \mathrm{ng} / \mathrm{ml}$ (range $0,5-17,5)$ and the difference was statistically significant $(\mathrm{p}=0,001)$. Mean leptin concentrations in our pts remained within normal ranges according to manufacturer's data. Leptin level was above normal range in 1 male patient due to high BMI $\left(30,3 \mathrm{~kg} / \mathrm{m}^{2}\right)$. Leptin levels below normal range were observed in $23 \mathrm{pts}$ (18 women and 5 men) and were associated with BMI $<20 \mathrm{~kg} / \mathrm{m}^{2}$ in 8 pts ( 7 women and 1 man). 
Leptin concentrations correlated positively with BMI both in women $\left(r_{S}=0,58, p=0,0001\right)$ and in men $\left(r_{S}=0,94, p=0,002\right)$. There was a positive correlation between leptin levels and TSF $\left(\mathrm{r}_{\mathrm{S}}=0,59, \mathrm{p}=0,0001\right)(\mathrm{Tab} . \mathrm{III})$.

A borderline, negative correlation was observed between leptin concentration and MDRD GFR $\left.\left(r_{S}=-0,22, p=0,05\right)\right)$ Tab. III).

There were positive correlations between serum leptin levels and TC levels $\left(r_{S}=0,32\right.$, $\mathrm{p}=0,004)$ and between leptin and LDL-cholesterol levels $\left(\mathrm{r}_{\mathrm{S}}=0,34, \mathrm{p}=0,003\right)$ (Tab. III).

\section{Adipokines serum concentrations in pts with long long-standing RA}

When assessing pts with long-standing RA we found negative correlations between adiponectin levels and markers of disease activity: number of tender joints $\left(r_{S}=-0,38, p=\right.$ $0,02)$, number of swollen joints $\left(\mathrm{r}_{\mathrm{S}}=-0,45, \mathrm{p}=0,003\right)$ and a borderline correlation with DAS28 $\left(r_{S}=-0,31, p=0,05\right)($ Tab. III).

Stepwise multiple regression analysis demonstrated a positive relationship between DAS28 value and leptin level in pts with long-standing $R A\left(R^{2}=0,158, p=0,01\right)$.

\section{Discussion}

In the presented group of RA pts, the mean serum concentrations of adiponectin and leptin remained within normal ranges. However, adipokines' levels were changing in the course of the disease. Adiponectin concentration was significantly higher in the group of pts with longstanding RA in comparison with pts with disease duration $<10$ years. That relationship was noted in spite of comparable inflammatory disease activity in both groups. It was observed, that adiponectin concentration significantly increased in relation with the increasing age of pts and disease duration. Additionally, there was a correlation between adiponectin concentration and the value of MDRD GFR, which is a good indicator of renal function, much better than serum creatinine concentration or creatinine clearance [25]. The observation indicates, that increasing adiponectin level might be associated with progressive reduction of glomerular filtration rate in the course of the disease. 
Our results support the idea, that adipokines influence the inflammatory process activity in the course of RA. Negative correlations between adiponectin concentrations and symptoms of joint disease activity (number of tender and swollen joints, DAS28 value) contribute to the anti-inflammatory adiponectin function. In contrast, leptin concentration was positively related to DAS28 value, which may be connected with the proinflammatory leptin role.

There were also significant correlations between concentrations of adipokines and lipid profile components. It was observed, that the increased adiponectin level was associated with increased HDL-cholesterol, whereas increased leptin level was related to increased TC and LDL-cholesterol levels. The observation suggests a protective metabolic function of adiponectin and proatherogenic leptin role.

Consistently with reports in literature, in our group of pts leptin levels were significantly higher in women than in men and correlated positively with markers of nutritional status (BMI and TSF). TSF is an objective parameter of nutritional status and gives information about fat mass exclusively [26].

According to the literature, leptin levels are higher in women than in men. Circulating leptin levels are directly correlated with WAT mass and BMI $[4,12,20]$. We did not find a relationship between adiponectin and BMI or TSF, similarly to the previous reports [27, 28]. Nakatani et al. reported, that in Japanese adults adiponectin levels correlated negatively with BMI, TC, TG and positively with HDL-cholesterol [29]. We found no reports on relationship between adipokines and lipid profile changes in RA pts.

Increasing number of reports describing differential and conflicting results, have been presented in literature on adipokines' role in inflammatory diseases and in RA.

The evidence shows, that leptin acts as a pro-inflammatory cytokine. From a structural point of view leptin belongs to the type 1 cytokine superfamily. It may be produced not only by adipocytes, but also by inflammatory cells. Different inflammatory stimuli (TNF- $\alpha$, IL-1, IL- 
6, lipopolysaccharide) regulate leptin mRNA expression and circulating levels, suggesting that short-time release of stored leptin is associated with acute inflammation. Leptin induces T-cell activation and modifies $\mathrm{T}$-cell differentiation towards $\mathrm{Th}_{1}$ response, connected with pro-inflammatory function [30]. In chronic inflammation prolonged stimulation induces a supression of leptin synthesis [12, 30].

In RA pts leptin concentrations were found to be similar to those of healthy controls $[13,14$, $15,16]$ and pts with osteoarthritis (OA) [20]. No correlation was reported between serum leptin levels and disease stages or disease activity, defined with the value of ESR, CRP [14, 16], DAS [13, 20] or presence of joint erosions [16]. In contrast, Popa et al reported that in RA pts plasma leptin concentration was inversely correlated with markers of inflammation (Il-6, CRP), suggesting, that long term stimulation of WAT by pro-inflmmatory cytokines inhibits leptin production [15]. Lee et al. reported significantly higher serum leptin levels in RA pts with high disease activity, as well as positive correlations between leptin and DAS28, CRP values [31]. In other publications, leptin levels were reported to be significantly higher in RA pts than in control subjects [18, 19, 21, 32], significantly correlated with CRP [21] or had no correlation with clinical and laboratory parameters of disease activity [32]. Bokarewa et al found that leptin plasma concentrations were higher than in synovial fluid samples obtained simultaneously. Decreased leptin level in synovial fluid was associated with nonerosive joint disease, suggesting a protective leptin effect against RA destruction [18].

Earlier, when assessing the group of 37 RA pts, we found that leptin concentrations were significantly higher in pts with erosive joint disease than in pts without erosions. In pts with long-standing RA leptin levels correlated positively with value of DAS28, ESR and number of tender joints. There was also a tendency of correlation between leptin level and cystatin C concentration (novel renal function parameter). The results suggested, that leptin levels were increased in pts with higher disease activity and the risk of progressive joint destruction [12]. 
In the present study we confirmed the observation of proinflammatory leptin function in the course of RA. Additional observation on the metabolic role of leptin were also performed.

Many reports have been published in the field of endocrinology and CVD, dealing with the protective metabolic role of adiponectin (anti-diabetic, anti-atherogenic), although little is known on the adiponectin function in inflammatory diseases, such as RA.

Adiponectin itself reduces the release of pro-inflammatory cytokines and increases production of ant-inflammatory ones from activated inflammatory cells. Pro-inflammatory cytokines (TNF- $\alpha$, IL-6) suppress adiponectin production and thus an inverse correlation has been noted between adiponectin concentration and markers of inflammation (CRP, IL-6) [33]. Chronic inflammation associated with obesity, diabetes, atherosclerosis and CVD is characterized by decreased adiponectin level [33]. Recently there has been a growing interest in adiponectin role in pts with CHF. High plasma levels of adiponectin observed in pts with established CHF were associated with poor prognosis and mortality. Reduced renal clearance could account for higher adiponectin concentration in CHF pts [34]. In haemodialysis pts low plasma adiponectin levels were associated with pre-existing CVD and predicted mortality outcomes $[35]$.

Some reports suggest, that in joint diseases adiponectin might exert pro-inflammatory effects. Adiponectin can induce the cultured synovial fibroblasts to release mediators of joint destruction: Il-6 and metalloproteinase-1 (MMP-1), but not TNF- $\alpha$ and IL-1 $\beta$ [36]. High concentrations of adiponectin were observed in synovial fluid of RA pts with synovial fibroblasts distinctly rich in adiponectin [37]. In contrast, Lee et al. observed, that adiponectin significantly mitigated the severity of arthritis in collagen-induced arthritis in mice, with decreased expression of TNF- $\alpha$, IL-1 $\beta$, MMP-3 in RA synovial fibroblasts. These data suggest an anti-inflammatory adiponectin role in the pathophysiology of RA [38]. 
In clinical observations, it was reported, that adiponectin plasma levels of RA pts did not differ significantly [21] or were markedly increased in comparison with healthy controls [21, 27]. No correlation was found between adiponectin and systemic inflammatory markers (CRP, ESR) [27] or a positive correlation with CRP was noted [21]. Increased adiponectin concentrations were observed in synovial fluid of RA in comparison with OA pts, which suggests a pro-inflammatory role in arthritis [27, 39]. Serum adiponectin levels were higher than those in synovial fluid, indicating, that peripheral fat stores are major producers of serum adiponectin [27].

Recent reports in literature demonstrate, that anti-TNF treatment was associated with an increase $[8,22,28,39]$ or no change in adiponectin levels [40]. The adiponectin levels were positively correlated with the endothelium-dependent vasodilatation and negatively with DAS28 [8]. Other reports demonstrated no correlation between adiponectin and clinical backgrounds or markers of disease activity after anti-TNF treatment [28, 41].

\section{Conclusions}

Although adiponectin and leptin concentrations remained within normal ranges in RA pts, a significant increase of adiponectin level was observed in relation to the age and disease duration. That might be connected with decreased GFR in older pts. Significant correlations between adipokines' concentrations and lipid profile components confirm their involvement in the process of atherosclerosis: protective adiponectin effect and proatherogenic leptin function. In pts with long-standing RA adipokines' concentrations were significantly associated with the joints disease activity, indicating anti-inflammatory adiponectin and proinflammatory leptin role. 


\section{List of abreviations}

Rheumatoid arthritis (RA), cardiovascular disease (CVD), coronary artery disease (CAD), chronic heart failure (CHF), osteoarthritis (OA), body cell mass (BCM), disease activity 28 joints score (DAS28), body mass index (BMI), tricipital skin fold (TSF), tumor necrosis factor- $\alpha$ (TNF- $\alpha$ ), interleukin-1 $\beta$ (IL-1 $\beta$ ), metalloproteinase-1 (MMP-1), white adipose tissue (WAT).

The authors declare that they have no competing interests. 


\section{References.}

1. Kremers HM, Nicola PJ, Crowson CS, Ballman KV, Gabriel SE: Prognostic importance of low body mass index in relation to cardiovascular mortality in rheumatoid arthritis. Arthritis Rheum 2004, 50: 3450- 3457.

2. Naranjo A, Sokka T, Descalzo MA, Calvo-Alén J, Hørslev-Petersen K, Luukkainen RK, Combe B, Burmester GR, Devlin J, Ferraccioli G, Morelli A, Hoekstra M, Majdan M, Sadkiewicz S, Belmonte M, Holmqvist AC, Choy E, Tunc R, Dimic A, Bergman M, Toloza S, Pincus T; QUEST-RA Group: Cardiovascular disease in patients with rheumatoid arthritis: results from the QUEST-RA study. Arthritis Res Ther. 2008, 10 (2):R30. Epub 2008 Mar 6

3. Walsmith $\mathrm{J}$, Abad L, Kehayias $\mathrm{J}$, Roubenoff $\mathrm{R}$ : Tumor necrosis factor- $\alpha$ production is associated with less body mass in women with rheumatoid arthritis. J Rheumatol 2004, 31: 23- 29

4. Toussirot É, Streit G, Wendling D: The contribution of adipose tissue and adipokines to inflammation in joint diseases. Curr Med Chemistry 2007, 14: 1095- 1100

5. Mafra D, Guebre-Egziabher F, Fouque D: Body mass index, muscle and fat in chronic kidney disease: questions about survival. Nephrol Dial Trensplant 2008, 23: 24612466

6. Almehed K, Forsblad d'Elia H, Bokarewa M, Carlsten H: Role of resistin as a marker of inflammation in systemic lupus erythematosus. Arthritis Res Ther 2008, 10: R15. Epub 2008 Jan 30

7. Sidiropoulos PI, Karvounaris SA, Boumpas DT: Metabolic syndrome in rheumatic diseases: epidemiology, pathophysiology, and clinical implications. Arthritis Res Ther. 2008, 10:207. Epub 2008 May 8 
8. Komai N, Morita Y, Sakuta T, Kuwabara A, Kashihara N: Anti-tumor necrosis factor therapy increases serum adiponectin levels with the improvement of endothelial dysfunction in patients with rheumatoid arthritis. Mod Rheumatol 2007, 17: 385- 390

9. Otero M, Lago R, Lago F, Casanueva FF, Dieguez C, Gómez-Reino JJ, Gualillo O: Leptin, from fat to inflammation: old questions and new insights. FEBS Lett 2005, 579: 295- 301

10. Bernotiene E, Palmer G, Gabay C: The role of lepin in innate and adaptive immune response. Arthritis Res Ther 2006, 8: 217- 226

11. Palmer G, Gabay C: A role for leptin in rheumatic diseases? Ann Rheum Dis 2003, 62: 913- 915

12. Targońska-Stępniak $B$, Majdan $M$, Dryglewska M: Leptin serum levels in rheumatoid arthritis patients: relation to disease duration and activity. Rheumatol Int 2008, 28: 585- 591

13. Anders H, Rihl M, Heufelder A, Loch $O$, Schattenkirchner M: Leptin serum levels are not correlated with disease activity in patients with rheumatoid arthritis. Metabolism 1999, 48: 745- 748

14. Nishiya K, Nishiyama M, Chang A, Shinto A, Hashimoto K: Serum leptin levels in patients with rheumatoid arthritis are correlated with body mass index. Rinsho Byori 2002, 50: 524- 527

15. Popa C Netea MG, Radstake TRDS, van Riel PL, Barrera P, van der Meer JWM: Markers of inflammation are negatively correlated with serum leptin in rheumatoid arthritis. Ann Rheum Dis 2005, 64: 1195- 1198

16. Hizmetli S, Kisa M, Gokalp N, Bakici MZ: Are plasma and synovial fluid leptin levels correlated with disease activity in rheumatoid arthritis? Rheumatol Int 2007, 27: 335338 
17. Tokarczyk-Knapik A, Nowicki M, Wyroślak J: The relation between plasma leptin concentration and body fat mass in patients with rheumatoid arthritis. Pol Arch Med. Wewn 2002, 108: 761- 767

18. Bokarewa M, Bokarew D, Hultgren $O$, Tarkowski A: Leptin consumption in the inflamed joints of patients with rheumatoid arthritis. Ann Rheum Dis 003, 62: 952956

19. Salazar-Paramo M, Gonzalez-Ortiz M, Gonzalez-Lopez L, Sanchez-Ortis A, ValeraGonzalez IC, Martinez-Abundis E, Balcazar-Munoz BR, Garcia-Gonzalez A, GamezNava JI: Serum leptin levels in patients with rheumatoid arthritis. $J$ Clin Rheumatol 2001, 7: 57- 59

20. Wisłowska M, Rok M, Jaszczyk B, Stępień K, Cicha M: Serum leptin in rhaumatoid arthritis. Rheumatol Int 2007, 27: 947- 954

21. Otero M, Lago R, Gómez R, Lago F, Dieguez C, Gómez-Reino JJ, Gualillo O: Changes in plasma levels of fat-derived hormones adiponectin, leptin, resistin and visfatin in patients with rheumatoid arthritis. Ann Rheum Dis 2006, 65: 1198- 1201

22. Nagashima T, Okubo-Fornbacher H, Aoki Y, Kamata Y, Kimura H, Kamimura T, Nara $\mathrm{H}$, Iwamoto $\mathrm{M}$, Yoshio $\mathrm{T}$, Okazaki $\mathrm{H}$, Minota $\mathrm{S}$ : Increase in plasma levels of adiponectin after administration of anti-tumor necrosis factor agents in patients with rheumatoid arthritis. J Rheumatol 2008, 35: 936- 938

23. Arnett FC, Edworthy SM, Bloch DA, McShane DJ, Fries JF, Cooper NS: The American Rheumatism Association 1987 revised criteria for the classification of rheumatoid arthritis. Arthritis Rheum 1988, 31: 315- 324

24. Steinbrocker O, Treger $\mathrm{H}$, Cornelius $\mathrm{H}$ : Therapeutic criteria in rheumatoid arthritis. JAMA 1949, 140: 659- 662 
25. Levey AS, Coresh J, Greene T, Marsh J, Stevens LA, Kusek JW, Van Lente F: Expressing the modification of diet in renal disease study equation for estimating glomerular filtration rate with standardized serum creatinine values. Clin Chem 2007, 53: 766-772

26. Gómez-Vaquero C, Nolla JM, Fiter J, Ramon JM, Concustell R, Valverde J, Roig-Escofet D: Nutritional status in patients with rheumatoid arthritis. Joint Bone Spine 2001, 68: 403- 409

27. Šenolt L, Pavelka K, Housa D, Haluzík M: Increased adiponectin is negatively linked to the local inflammatory process in patients with rheumatoid arthritis. Cytokine 2006, 35: 247- 252

28. Nishida K, Okada Y, Nawata M, Saito K, Tanaka Y: Induction of hyperadiponectemia following long-term treatment of patients with rheumatoid arthritis with infliximab (IFX), an anti-TNF-alpha antibody. Endocrine J 2008, 55: 213- 216

29. Nakatani H, Hirose H, Yamamoto Y, Saito I, Itoh H: Significance of leptin and highmolecular weight adiponectin in the general population of Japanese male adolescents. Metabol Clin Exp 2008, 57: 157- 162

30. Lago R, Gómez R, Lago F, Gómez-Reino J, Gualillo O: Leptin beyond body weight regulation- Current concepts concerning its role in immune function and inflammation. Cell Immunol 2008, 252: 139- 145

31. Lee SW, Park MC, Park YB, Lee SK: Measurement of the serum leptin levelcould assist disease activity monitoring in rheumatoid arthritis. Rheumatol Int 2007, 27: 537- 540

32. Gunaydin R, Kaya T, Atay A, Olmez N, Hur A, Koseoglu M: Serum leptin levels in rheumatoid arthritis and relationship with disease activity. South Med J 2006, 99: 1078- 83 
33. Fantuzzi G: Adiponectin and inflammation: Consensus and controversy. J Allergy Clin Immunol 2008, 121: 326- 330

34. McEntegart MB, Awede B, Petrie MC, Sattar N, Dunn FG, MacFarlane NG, McMurray JJV: Increase in serum adiponectin concentration in patients with heart failure and cachexia: relationship with leptin, other cytokies, and B-type natriuretic peptide. Eur Heart J 2007, 28: 829- 835

35. Rao M, Li L, Tighiouart H, Jaber BL, Pereira BJG, Balakrishnan VB: Plasma adiponectin levels and clinical outcomes among haemodialysis patients. Nephrol Dial Transplant 2008, 23: 2619- 2628

36. Ehling A, Schäffler A, Herfarth H, Tarner IH, Anders S, Distler O, Paul G, Distler S, Schölmerich J, Neumann E, Müller-Ladner U: The potential of adiponectin in driving arthritis. J Immunol 2006, 176: 4468- 4478

37. Tan W, Wang F, Zhang M, GuoD, Zhang Q, He S: High adiponectin and adiponectin receptor 1 expression in synovial fluids and synovial tissues of patients with rheumatoid arthritis. Semin Arthritis Rheum 2008, 4: in press

38. Lee SW, Kim JH, Park MC, Park YB, Lee SL: Adiponectin mitigates the severity of arthritis in mice with collagen-induced arthritis. Scand J Rheumatol 2008, 37: 260268

39. Schäffler A, Ehling A, Neumann E, Herfarth H, Tarner I, Schölmerich J, Müller-Ladner U,: Adipocytokines in synovial fluid. JAMA 2003, 290: 1709- 1710

40. Hörle P, Sarzi-Puttini P, Cutolo M, Straub RH: No change of serum levels of leptin and adiponectin during anti-tumor necrosis factor antibody treatment with adalimumab in patients with rheumatoid arthritis. Ann Rheum Dis 2006, 65: 970- 971 
41. Serelis J, Kontogianni MD, Katsiougiannis S, Bletsa M, Tektonidou MG, Skopouli FN: Effect of anti-TNF treatment on body composition and serum adiponectin levels of women with rheumatoid arthritis. Clin Rheumatol 2008, 27: 795- 797 

Figure 1. Serum adiponetin levels in pts with RA of duration $<10$ years and $>10$ years $(\mathrm{p}=0,047)$.

Table I. Basic characteristics of 80 RA pts

\begin{tabular}{|c|c|}
\hline Variable & Value \\
\hline Gender (F/M) & $72(90 \%) / 8(10 \%)$ \\
\hline Age (years) & $53,7(13,1)$ (range 19-89) \\
\hline Disease duration (months) & 131,9 (93,7) (range 3- 420) \\
\hline Long-standing RA (> 10 years) & $40(50 \%)$ \\
\hline Erosive RA & $59(73,8 \%)$ \\
\hline Extra-articular symptoms & $39(48,8 \%)$ \\
\hline RF positivity & $52(65 \%)$ \\
\hline $\operatorname{ESR}(\mathrm{mm} / \mathrm{h})$ & $44,6(26,1)$ (range 9- 125) \\
\hline $\mathrm{CRP}(\mathrm{mg} / \mathrm{l})$ & $29,5(28,6)($ range $1,0-110,7)$ \\
\hline DAS28 (0- 10) & $5,54(1,4)($ range $2,1-8,4)$ \\
\hline Serum albumin (g/dl) & $3,86(0,6)($ range $1,9-5,0)$ \\
\hline Hemoglobin $(\mathrm{g} / \mathrm{dl})$ & $12,01(1,3)$ (range $9,0-15,2)$ \\
\hline BMI $\left(\mathrm{kg} / \mathrm{m}^{2}\right)$ & $25,2(4,4)$ (range $17,0-36,9)$ \\
\hline TSF (mm) & $20,2(7,7)($ range $5,5-41,0)$ \\
\hline Creatinine (mg/dl) & $0,84(0,2)($ range $0,6-1,6)$ \\
\hline MDRD GFR $\left(\mathrm{ml} / \mathrm{min} / 1,73 \mathrm{~m}^{2}\right)$ & $81,1(17,4)$ (range $34-113)$ \\
\hline
\end{tabular}

Values are: mean (SD) or $\mathrm{n}(\%)$

Table II. Characteristics of pts with disease duration $\leq 10$ years and $>10$ years.

\begin{tabular}{|l|l|l|l|}
\hline Variable & RA duration $\leq \mathbf{1 0}$ years & RA duration $>\mathbf{1 0}$ years & p \\
\hline Gender $(\mathrm{F} / \mathrm{M})$ & $35(87,5 \%) / 5(12,5 \%)$ & $37(92,5 \%) / 3(7,5 \%)$ & $\mathrm{NS}$ \\
\hline Age $($ years $)$ & $50,4(12,3)$ & $56,9(13,2)$ & $* 0,02$ \\
\hline
\end{tabular}




\begin{tabular}{|c|c|c|c|}
\hline Disease duration (months) & $62,4(38,3)$ & $201,5(79,8)$ & $*<0,001$ \\
\hline Erosive RA & $22(55 \%)$ & $37(92,5 \%)$ & $* 0,004$ \\
\hline Extra-articular symptoms & $16(40 \%)$ & $23(57,5 \%)$ & NS \\
\hline RF positivity & $23(57,5 \%)$ & $29(72,5 \%)$ & NS \\
\hline High disease activity (DAS28>5,1) & $24(60 \%)$ & $26(65 \%)$ & NS \\
\hline ESR $(\mathrm{mm} / \mathrm{h})$ & $44,8(28,8)$ & $44,4(23,5)$ & NS \\
\hline CRP (mg/l) & $30,0(26,4)$ & $29,1(30,9)$ & NS \\
\hline DAS28 (0- 10) & $5,52(1,5)$ & $5,6(1,4)$ & NS \\
\hline Hemoglobin $(\mathrm{g} / \mathrm{dl})$ & $11,8(1,6)$ & $12,1(1,2)$ & NS \\
\hline $\mathrm{TC}(\mathrm{mg} / \mathrm{dl})$ & $201,7(45,6)$ & $223,7(60,9)$ & NS \\
\hline HDL-cholestrol (mg/dl) & $56,5(12,1)$ & $62,1(17,9)$ & NS \\
\hline \begin{tabular}{|l|} 
LDL-cholesterol (mg/dl) \\
\end{tabular} & $119,7(35,5)$ & $130,5(46,7)$ & NS \\
\hline TG (mg/dl) & $135,0(61,9)$ & $137,4(59,3)$ & NS \\
\hline Serum albumin $(\mathrm{g} / \mathrm{dl})$ & $3,83(0,5)$ & $3,88(0,6)$ & NS \\
\hline BMI $\left(\mathrm{kg} / \mathrm{m}^{2}\right)$ & $25,0(4,4)$ & $25,4(4,4)$ & NS \\
\hline TSF (mm) & $20,4(7,6)$ & $20,02(7,9)$ & NS \\
\hline Creatinine $(\mathrm{mg} / \mathrm{dl})$ & $0,86(0,2)$ & $0,83(0,2)$ & NS \\
\hline MDRD GFR $\left(\mathrm{ml} / \mathrm{min} / 1,73 \mathrm{~m}^{2}\right)$ & $80,7(18,6)$ & $81,5(16,6)$ & NS \\
\hline Adiponectin (ug/ml) & $12,7(6,4)$ & $17,7(11,2)$ & $* 0,02$ \\
\hline Leptin $(\mathrm{ng} / \mathrm{ml})$ & $11,2(11,9)$ & $9,5(7,1)$ & NS \\
\hline
\end{tabular}

Values are: mean (SD) or $\mathrm{n}(\%)$

Table III. Correlations between serum adiponectin, leptin levels and parameters in RA pts.

\begin{tabular}{|c|c|c|}
\hline Variable & Adiponectin & Leptin \\
\hline \multicolumn{3}{|c|}{ The group of $80 \mathrm{RA}$ pts } \\
\hline Age & $\mathrm{r}=0,32(\mathrm{p}=0,003)$ & NS \\
\hline Disease duration & $\mathrm{r}=0,38(\mathrm{p}=0,0006)$ & NS \\
\hline BMI & NS & $\begin{array}{l}F: r=0,58(p=0,0001) \\
M: r=0,94(p=0,002)\end{array}$ \\
\hline TSF & NS & $\mathrm{r}=0,59(\mathrm{p}=0,0001)$ \\
\hline MDRD GFR & $r=-0,23(p=0,04)$ & $\mathrm{r}=-0,22(\mathrm{p}=0,05)$ \\
\hline
\end{tabular}




\begin{tabular}{|l|l|l|}
\hline Total cholestrol & $\mathrm{NS}$ & $\mathrm{r}=0,32(\mathrm{p}=0,004)$ \\
\hline HDL-cholestrol & $\mathrm{r}=0,40(\mathrm{p}=0,0003)$ & $\mathrm{NS}$ \\
\hline LDL-cholesterol & $\mathrm{NS}$ & $\mathrm{r}=0,34(\mathrm{p}=0,003)$ \\
\hline \multicolumn{2}{|l|}{ The group of 40 pts with long-standing RA $(>10$ years $)$} \\
\hline Tender joints count & $\mathrm{r}=-0,38(\mathrm{p}=0,02)$ & $\mathrm{NS}$ \\
\hline Swollen joints count & $\mathrm{r}=-0,45(\mathrm{p}=0,003)$ & $\mathrm{NS}$ \\
\hline DAS28 & $\mathrm{r}=-0,31(\mathrm{p}=0,05)$ & $\mathrm{NS}$ \\
\hline
\end{tabular}

r- Spearman correlation, NS- not significant, F- female, M- male

Figure 1. Serum adiponetin levels in pts with RA of duration $<10$ years and $>10$ years $(\mathrm{p}=0,047)$.

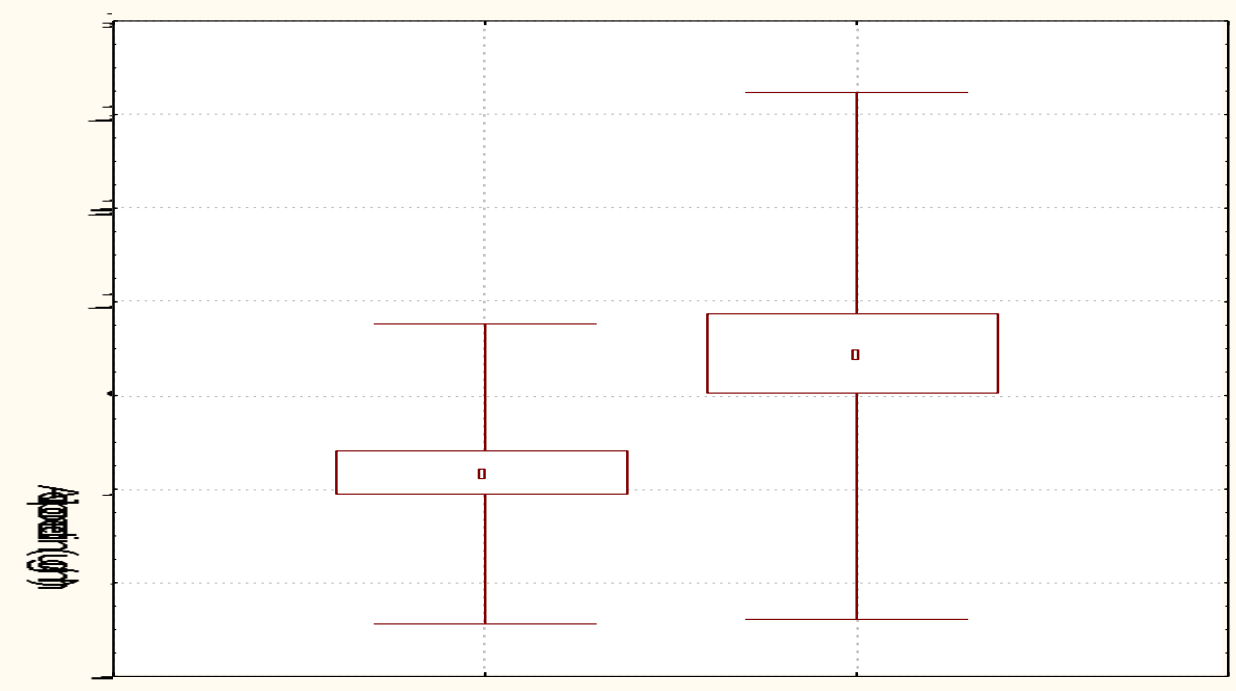

